\title{
Article \\ Isolation, Identification and Pharmacological Effects of Mandragora autumnalis Fruit Flavonoids Fraction
}

\author{
Nawaf Al-Maharik ${ }^{1, *}$, Nidal Jaradat ${ }^{2, *} \mathbb{( \mathbb { D }}$, Najlaa Bassalat ${ }^{3} \mathbb{D}$, Mohammed Hawash $^{2} \mathbb{D}$ and Hilal Zaid ${ }^{4}$ \\ 1 Division of Chemistry, Faculty of Science, An-Najah National University, Nablus 00970, Palestine \\ 2 Department of Pharmacy, Faculty of Medicine and Health Sciences, An-Najah National University, \\ Nablus 00970, Palestine; mohawash@najah.edu \\ 3 Department of Biology and Biotechnology, Faculty of Sciences, Arab American University, \\ Jenin P.O. Box 240, Palestine; nbassalat@gmail.com \\ 4 Qasemi Research Center, Faculty of Medicine, Al-Qasemi Academic College, Arab American University, \\ Jenin P.O. Box 240, Palestine; hilal.zaid@gmail.com \\ * Correspondence: n.maharik@najah.edu (N.A.-M.); nidaljaradat@najah.edu (N.J.)
}

Citation: Al-Maharik, N.; Jaradat, N.; Bassalat, N.; Hawash, M.; Zaid, H. Isolation, Identification and Pharmacological Effects of Mandragora autumnalis Fruit Flavonoids Fraction. Molecules 2022, 27, 1046. https://doi.org/10.3390/ molecules27031046

Academic Editor: George Grant

Received: 27 December 2021

Accepted: 31 January 2022

Published: 3 February 2022

Publisher's Note: MDPI stays neutral with regard to jurisdictional claims in published maps and institutional affiliations.

Copyright: (C) 2022 by the authors. Licensee MDPI, Basel, Switzerland. This article is an open access article distributed under the terms and conditions of the Creative Commons Attribution (CC BY) license (https:// creativecommons.org/licenses/by/ $4.0 /)$.

\begin{abstract}
Since ancient times, Mandragora autumnalis has been used as a traditional medicinal plant for the treatment of numerous ailments. In light of this, the current study was designed to isolate and identify the chemical constituents of the flavonoids fraction from M. autumnalis ripe fruit (FFM), and evaluate its DPPH scavenging, anti-lipase, cytotoxicity, antimicrobial and antidiabetic effects. An ethyl acetate extract of $M$. autumnalis was subjected to a sequence of silica gel column chromatography using different eluents with various polarities. The chemical structures of the isolated compounds were identified using different spectral techniques, including ${ }^{1} \mathrm{H} N \mathrm{NR}$ and ${ }^{13} \mathrm{C}$ NMR. FFM's anti-diabetic activity was assessed using a glucose transporter-4 (GLUT4) translocation assay, as well as an inhibition against $\alpha$-amylase and $\alpha$-glucosidase using standard biochemical assays. The FFM anti-lipase effect against porcine pancreatic lipase was also evaluated. Moreover, FFM free radical scavenging activity using the DPPH test and antimicrobial properties against eight microbial strains using the micro-dilution method were also assessed. Four flavonoid aglycones were separated from FFM and their chemical structures were identified. The structures of the isolated compounds were established as kaempferol 1, luteolin 2, myricetin 3 and (+)-taxifolin 4, based on NMR spectroscopic analyses. The cytotoxicity test results showed high cell viability (at least $90 \%$ ) for up to $1 \mathrm{mg} / \mathrm{mL}$ concentration of FFM, which is considered to be safe. A dose-dependent increase in GLUT4 translocation was significantly shown $(p<0.05)$ when the muscle cells were treated with FFM up to $0.5 \mathrm{mg} / \mathrm{mL}$. Moreover, FFM revealed potent $\alpha$-amylase, $\alpha$-glucosidase, DPPH scavenging and porcine pancreatic lipase inhibitory activities compared with the positive controls, with $\mathrm{IC}_{50}$ values of $72.44 \pm 0.89,39.81 \pm 0.74,5.37 \pm 0.41$ and $39.81 \pm 1.23 \mu \mathrm{g} / \mathrm{mL}$, respectively. In addition, FFM inhibited the growth of all of the tested bacterial and fungal strains and showed the greatest antibacterial activity against the K. pneumoniae strain with a MIC value of $0.135 \mu \mathrm{g} / \mathrm{mL}$. The four flavonoid molecules that constitute the FFM have been shown to have medicinal promise. Further in vivo testing and formulation design are needed to corroborate these findings, which are integral to the pharmaceutical and food supplement industries.
\end{abstract}

Keywords: Mandragora autumnalis; flavonoids; cytotoxicity; antidiabetic; anti-obesity; DPPH scavenging; antimicrobial

\section{Introduction}

Humankind has been fascinated with botanicals since antiquity because of their exceptional nutritional, cosmetic and medicinal characteristics [1]. A growing body of evidence shows that herbal medicines have fewer side effects than most synthetic treatments, making them an important source for the development of new pharmaceuticals, cosmetics and nutritional supplements [2]. It is a controversial subject in the medical and pharmaceutical 
sectors to study natural products for their pharmacological properties [3]. Consequently, biological and chemical screenings of wild herbs are essential in the creation of new medicinal and functional food products.

Mandragora autumnalis Bertol. (also known as Mandragora officinarum L.) is a highly valued wild medicinal herb. It is a perennial herbaceous plant in the Solanaceae family with purple or violet blooms and orange or yellow mature fruits (berries). It is widely distributed throughout the Mediterranean Basin, including Palestine. It is still used in traditional Arabian medicine, especially Palestinian herbal medicine, to treat pains, insomnia, cough, throat pain, bronchitis and various genital organs diseases [4,5]. M. autumnalis has antitumor [6], antioxidant and antimicrobial activities [7], as well as having free radicals, cholinesterase, tyrosinase, $\alpha$-amylase and $\alpha$-glucosidase inhibitory activities [8].

Due to the tendency of unripe fruits, leaves and roots to cause mental disorder and arouse the senses, it is known locally as Tufah Almajan (Satan's Apple), love apples and Beed Aljin (Eggs of the Jinn) [9]. Historically, inhabitants of the Islamic Empire used M. autumnalis dried ripe berries to treat metabolic risk factors such as diabetes and obesity, while its roots and leaves were used to treat a variety of illnesses, such as skin ulcers, infected wounds, pimples, warts, mouth inflammation, eye infections, pain, vomiting, male infertility and insomnia [10-12]. Previous phytochemical studies of $M$. autumnalis resulted in the isolation of 11 alkaloids, including calystegine A3 5, scopine 6 and a few coumarins such as scopoletin (4-methylesculetin) 7 as well as the steroid sitosterol 8 in various parts of M. autumnalis roots (Figure 1), fruits and leaves [11,13]. Furthermore, several withanolides (polyoxygenated steroidal lactones/lactols) such as mandragorolide A 9 were isolated from the M. autumnalis whole plant methanolic extract [14]. Flavonoids have never been extracted from any part of this plant, according to a review of the literature.

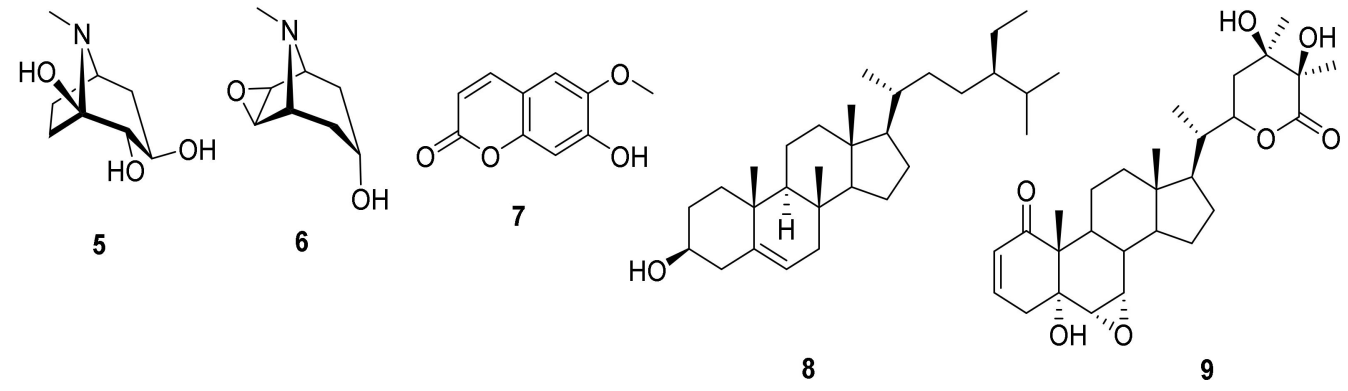

Figure 1. Phytochemicals isolated previously from M. autumnalis.

Noncommunicable diseases, including obesity, diabetes, oxidative stress and cancer, are considered among the most virulent diseases of the 21 st century. The combined burden of these diseases is rising fastest in communities where they impose large, unavoidable costs in human, social and economic terms [15].

The development of drug-resistant pathogens has occurred rapidly, while the emergence of multi-drug resistant strains has increased exponentially in recent years [16].

Despite a variety of measures taken in recent decades to address this problem, worldwide antimicrobial resistance trends show no indications of abating. One of the primary causes of the rise of antimicrobial resistance is the overuse and misuse of antimicrobial agents in both the healthcare and agricultural sectors. Microbial mutation and spontaneous evolution, as well as horizontal gene transfer that passes resistant genes on, all play important roles in the rise of antimicrobial resistance [17].

Following up on a previously conducted study that involved the identification of phytochemical composition and the assessment of biological activities of various wildgrowing herbs in Palestine, we have considered investigating the ethyl acetate fraction of the methanol extract of $M$. autumnalis ripe berries, identifying the chemical composition of this fraction and assessing its anti-obesity, DPPH scavenging, cytotoxic, antimicrobial and 
antidiabetic effect by measuring its action on the glucose transporter-4 (GLUT4) translocase, $\alpha$-amylase and $\alpha$-glucosidase properties.

\section{Results}

\subsection{Chemistry}

Identification of the Isolated Compounds

Four flavonoids (Figure 2) were isolated from the ethyl acetate (EtOAc) extract of the ripe fruit of M. autumnalis, and their structures were identified as kaempferol 1, luteolin 2, myricetin 3 and (+)-taxifolin (4) by comparing their ${ }^{1} \mathrm{H}$ - and ${ }^{13} \mathrm{C}-\mathrm{NMR}$ spectral analysis with that reported in the literature (Table 1, Figures S1-S14).

Table 1. ${ }^{1} \mathrm{H}$ and ${ }^{13} \mathrm{C}$ spectral data of $\mathbf{1 - 4}\left(\mathrm{DMSO}^{-} \mathrm{d}_{6}, 400 \mathrm{~Hz}, \delta\right.$ in ppm, J in $\mathrm{Hz}$ ).

\begin{tabular}{|c|c|c|c|c|c|c|c|c|}
\hline \multirow[b]{2}{*}{ C No } & \multicolumn{2}{|c|}{ Compound 1} & \multicolumn{2}{|c|}{ Compound 2} & \multicolumn{2}{|c|}{ Compound 3} & \multicolumn{2}{|c|}{ Compound 4} \\
\hline & $\delta_{\mathrm{C}}$ & $\delta_{\mathrm{H}}$ & $\delta_{\mathrm{C}}$ & $\delta_{\mathrm{H}}$ & $\delta_{\mathrm{C}}$ & $\delta_{\mathrm{H}}$ & $\delta_{\mathrm{C}}$ & $\delta_{\mathrm{H}}$ \\
\hline 1 & & & & & & & & \\
\hline 2 & 147.3 & & 169.1 & & 147.3 & & 72.0 & $\begin{array}{c}4.98 \\
\mathrm{~d}, J=11.2 \mathrm{~Hz}\end{array}$ \\
\hline 3 & 136.1 & & 108.1 & $\begin{array}{c}6.68 \\
s\end{array}$ & 136.3 & & 83.5 & $\begin{array}{c}4.50 \\
\mathrm{~d}, J=11.2,6.2 \mathrm{~Hz}\end{array}$ \\
\hline 4 & 176.4 & & 186.9 & & 176.2 & & 197.3 & \\
\hline $4 a$ & 103.5 & & 108.9 & & 103.4 & & 101.0 & \\
\hline 5 & 161.2 & & 166.7 & & 161.2 & & 163.8 & \\
\hline 6 & 98.7 & $\begin{array}{c}6.19 \\
\mathrm{~d}, J=2.1 \mathrm{~Hz}\end{array}$ & 103.9 & $\begin{array}{c}6.19 \\
\mathrm{~d}, J=2.1 \mathrm{~Hz}\end{array}$ & 98.6 & $\begin{array}{c}6.18 \\
\mathrm{~d}, J=2.1 \mathrm{~Hz}\end{array}$ & 95.4 & $\begin{array}{c}5.86 \\
\mathrm{~d}, J=2.1 \mathrm{~Hz}\end{array}$ \\
\hline 7 & 164.4 & & 169.3 & & 164.3 & & 167.3 & \\
\hline 8 & 94.0 & $\begin{array}{c}6.44 \\
\mathrm{~d}, J=2.1 \mathrm{~Hz}\end{array}$ & 99.4 & $\begin{array}{c}6.45 \\
\mathrm{~d}, J=2.1 \mathrm{~Hz}\end{array}$ & 93.7 & $\begin{array}{c}6.37 \\
\mathrm{~d}, J=2.1 \mathrm{~Hz}\end{array}$ & 96.4 & $\begin{array}{c}5.91 \\
\mathrm{~d}, J=2.1 \mathrm{~Hz}\end{array}$ \\
\hline $8 a$ & 159.67 & & 162.2 & & 156.5 & & 163.0 & \\
\hline $1^{\prime}$ & 122.1 & & 126.6 & & 121.2 & & 128.5 & \\
\hline $2^{\prime}$ & 130.0 & $\begin{array}{c}8.05 \\
\mathrm{~d}, J=8.9 \mathrm{~Hz}\end{array}$ & 118.3 & $\begin{array}{c}7.40 \\
\mathrm{~d}, J=2.2 \mathrm{~Hz}\end{array}$ & 107.6 & $\begin{array}{c}7.24 \\
\mathrm{~s}\end{array}$ & 115.8 & $\begin{array}{c}6.88 \\
\mathrm{~d}, J=1.6 \mathrm{~Hz}\end{array}$ \\
\hline $3^{\prime}$ & 115.9 & $\begin{array}{c}6.93 \\
\mathrm{~d}, J=8.9 \mathrm{~Hz}\end{array}$ & 150.7 & & 146.2 & & 144.9 & \\
\hline $4^{\prime}$ & 156.6 & & 154.9 & & 136.3 & & 145.4 & \\
\hline $5^{\prime}$ & 115.9 & $\begin{array}{c}6.93 \\
\mathrm{~d}, J=8.9 \mathrm{~Hz}\end{array}$ & 120.9 & $\begin{array}{c}6.89 \\
\mathrm{~d}, J=8.3 \mathrm{~Hz}\end{array}$ & 146.2 & & 115.6 & $\begin{array}{c}6.75 \mathrm{~m}, 2 \mathrm{H} \\
\text { overlap with H-6' }\end{array}$ \\
\hline $6^{\prime}$ & 130.0 & $\begin{array}{c}8.05 \\
\mathrm{~d}, J=8.9 \mathrm{~Hz} \\
2 \mathrm{H}\end{array}$ & 124.1 & $\begin{array}{c}7.43 \\
\mathrm{dd}, J=8.3 \\
2.2 \mathrm{~Hz}\end{array}$ & 107.6 & $\begin{array}{c}7.24 \\
s\end{array}$ & 119.9 & $\begin{array}{c}6.75 \\
\text { m, overlap with H-5' }\end{array}$ \\
\hline $3-\mathrm{OH}$ & & 10.80 & & & & 10.79 & & $\begin{array}{c}5.77 \\
\mathrm{~d}, J=6.2 \mathrm{~Hz}\end{array}$ \\
\hline $5-\mathrm{OH}$ & & 12.49 & & 12.99 & & 12.51 & & 11.92 \\
\hline $7-\mathrm{OH}$ & & 10.12 & & 10.85 & & 9.36 & & 10.85 \\
\hline $4^{\prime}-\mathrm{OH}$ & & 9.42 & & 9.95 & & 8.82 & & 9.05 \\
\hline $3^{\prime}-\mathrm{OH}$ & & & & 9.43 & & 9.23 & & 9.00 \\
\hline $5^{\prime}-\mathrm{OH}$ & & & & & & 9.23 & & \\
\hline
\end{tabular}

(+)-taxifolin (4): Pale yellow solid, $[\alpha]^{21}+52.3$ acetone $(c=0.25$, acetone). 
<smiles>O=C1c2c(O)cc(O)cc2O[C@H](c2ccc(O)c(O)c2)[C@@H]1O</smiles>

Figure 2. Chemical structures of the isolated compounds from FFM.

\subsection{Biological Evaluations}

\subsubsection{Cytotoxicity}

Following MTT assays, the toxicity of FFM was assessed in vitro in the L6-GLUT4 myc cell. Concentrations of FFM that preserved at least $90 \%$ cell viability were deemed to be safe. FFM was proven to be safe at concentrations of up to $1 \mathrm{mg} / \mathrm{mL}$. The cells' viability was the lowest at $1 \mathrm{mg} / \mathrm{mL}$ and reached $93 \pm 2 \%$. As a result, the effectiveness trials were carried out at lower dosages of up to $0.5 \mathrm{mg} / \mathrm{mL}$.

\subsubsection{GLUT4 Translocation to the Plasma Membrane}

Increasing GLUT4 translocation to the plasma membrane (PM) in muscle is an important action of insulin for maintaining glucose homeostasis. As expected, insulin enhanced GLUT4 translocation to the surface of myoblasts and thus increased glucose uptake. To examine the effect of FFM on GLUT4 translocation to the plasma membrane in the absence and presence of insulin, L6-GLUT4myc, the cells were exposed to increased concentrations of FFM for $20 \mathrm{~h}$. The effect of FFM was compared with that of the control and insulin (100 nM)-treated cells. Insulin-stimulated GLUT4 translocation to the PM by $1.66 \pm 0.25$ folds compared with vehicle untreated cells. A dose-dependent increase in GLUT4 translocation was significantly noticed $(p<0.05)$ when the muscle cells were treated with FFM in the absence and the presence of insulin, except at $0.125 \mathrm{mg} / \mathrm{mL}$. The FFM at concentrations of $0.125,0.25$ and $0.5 \mu \mathrm{g} / \mathrm{mL}$ significantly enhanced GLUT4 translocation $(p<0.05)$ at no insulin treatment by $1.33 \pm 0.13,1.33 \pm 0.22$ and $1.56 \pm 0.21 \mu \mathrm{g} / \mathrm{mL}$, respectively. The FFM also stimulated GLUT4 translocation to the PM in the presence of insulin significantly at 0.25 and $0.5 \mathrm{mg} / \mathrm{mL}$ by $2.35 \pm 0.43$ and $2.35 \pm 0.19$, respectively (Figure 3 ).

\subsection{3. $\alpha$-Amylase Inhibitory Potential}

The results revealed that FFM displayed $\alpha$-amylase inhibitory activity in a dosedependent manner compared with the commercial antidiabetic therapeutic agent acarbose, as indicated in Figure 4. However, the IC $\mathrm{IC}_{50}$ of FFM was $72.44 \pm 0.89 \mu \mathrm{g} / \mathrm{mL}$, while the $\mathrm{IC}_{50}$ of the positive control acarbose was $28.18 \pm 1.22 \mu \mathrm{g} / \mathrm{mL}$.

\subsection{4. $\alpha$-Glucosidase Inhibitory Activity}

The $\alpha$-glucosidase inhibitory activity of FFM was assessed and compared with that of the strong $\alpha$-glucosidase inhibitory agent (acarbose). In Figure 5, the $\alpha$-glucosidase inhibitory activity of FFM and acarbose was shown, and the $\mathrm{IC}_{50}$ of FFM against this enzyme was $39.81 \pm 0.74 \mu \mathrm{g} / \mathrm{mL}$, which is considered very close to the $\mathrm{IC}_{50}$ of the positive control acarbose, which was $37.15 \pm 0.33 \mu \mathrm{g} / \mathrm{mL}$.

\subsubsection{DPPH Scavenging Activity}

The ability of FFM to scavenge free oxygen radicals was assessed using the DPPH method, while trolox (vitamin E analog) was used as a positive control. The DPPH scav- 
enging activity of FFM and trolox is shown in Figure 6, with the $\mathrm{IC}_{50}$ of FFM being $5.37 \pm 0.41 \mu \mathrm{g} / \mathrm{mL}$, which is considered close to that of trolox $\left(\mathrm{IC}_{50}=2.23 \pm 1.23 \mu \mathrm{g} / \mathrm{mL}\right)$.

\subsubsection{Antilipase Activity}

The hydrolysis of $p$-nitrophenyl butyrate to $p$-nitrophenol was used to measure the influence of FFM on the porcine pancreatic lipase enzyme. The assay detected the inhibitory activity of FFM compared with orlistat, a strong lipase inhibitory agent. The results of the lipase enzyme inhibitory activity are shown in Figure 7 , and the $\mathrm{IC}_{50}$ of FFM against this enzyme was $39.81 \pm 1.23 \mu \mathrm{g} / \mathrm{mL}$, while the $\mathrm{IC}_{50}$ of the positive control orlistat was $12.56 \pm 0.35 \mu \mathrm{g} / \mathrm{mL}$.

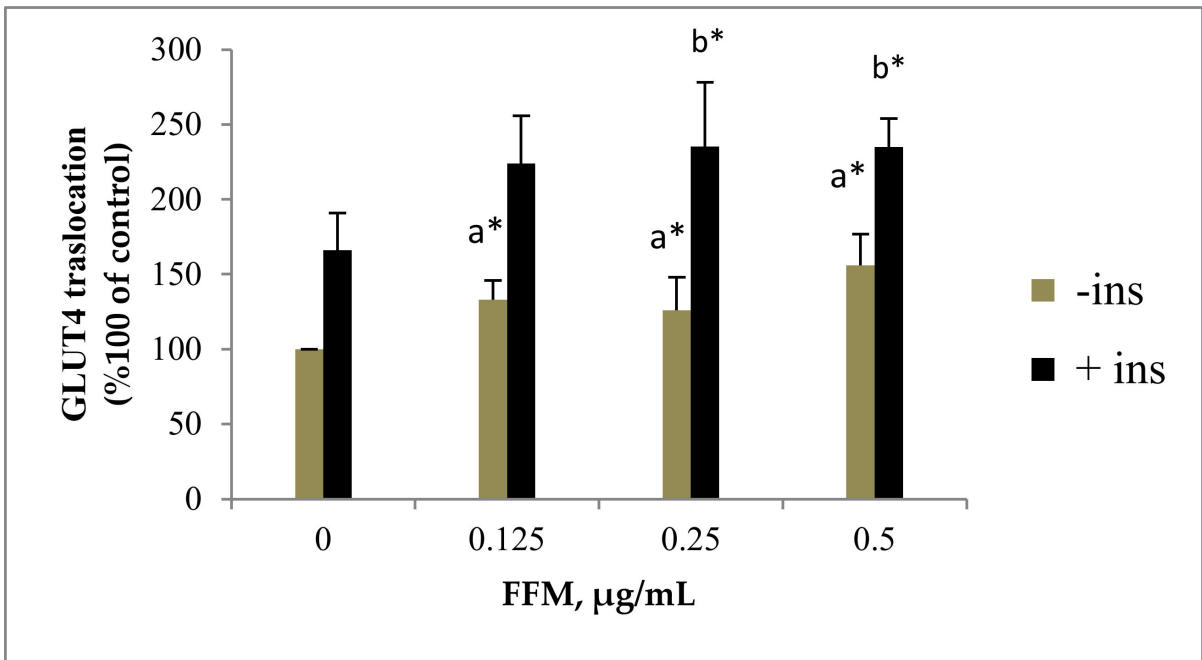

Figure 3. Effect of FFM on GLUT4 translocation. GLUT4 L6-GLUT4myc cells (100,000 cell/well) were exposed to FFM for $20 \mathrm{~h}$. Serum-depleted cells were treated without (-) or with (+) $1 \mathrm{nM}$ insulin for $20 \mathrm{~min}$ at $37^{\circ} \mathrm{C}$ and surface myc-tagged GLUT4 density was quantified using the antibody-coupled colorimetric assay. Values given represent means \pm SEM (\% of untreated control cells) of three independent experiments carried out in triplicates. ${ }^{*} p<0.05$; a: compared with - insulin control group, b: compared with + insulin control group.

\subsubsection{Antimicrobial Capacity}

The microdilution assay was used to evaluate the antimicrobial activity of the FFM against MRSA, S. aureus, E. faecium, S. sonnie, P. aeruginosa, E. coli, E. floccosum and C. albicans. The results revealed that FFM inhibited the growth of all of the tested Gram-positive and Gram-negative microbial strains, as indicated in Table 2.

Table 2. MIC values ( $\mu \mathrm{g} / \mathrm{mL})$ of FFM and positive controls.

\begin{tabular}{ccccc}
\hline Microbial Strains & Fluconazole & Ampicillin & Ciprofloxacin & FFM \\
\hline S. aureus & 0 & $3.12 \pm 0.02$ & $0.78 \pm 0.01$ & $1.5 \pm 0.07$ \\
E. faecium & 0 & $1.56 \pm 0.01$ & $0.78 \pm 0.02$ & $3.125 \pm 0.03$ \\
E. coli & 0 & $3.12 \pm 0.23$ & $1.56 \pm 0.08$ & $2.25 \pm 0.07$ \\
P. aeruginosa & 0 & $12.5 \pm 0.13$ & $3.12 \pm 0.11$ & $12.5 \pm 0.98$ \\
K. pneumoniae & 0 & $1 \pm 0.02$ & $15 \pm 0.02$ & $0.135 \pm 0.01$ \\
P. vulgaris & 0 & $60.5 \pm 0.71$ & $12.5 \pm 0.54$ & $22 \pm 0.97$ \\
MRSA & 0 & 0 & 0 & $25 \pm 1.01$ \\
E. floccosum & $0.78 \pm 0.01$ & 0 & 0 & $12.5 \pm 0.88$ \\
C. albicans & $1.56 \pm 0.01$ & & & $6.25 \pm 0.48$ \\
\hline
\end{tabular}




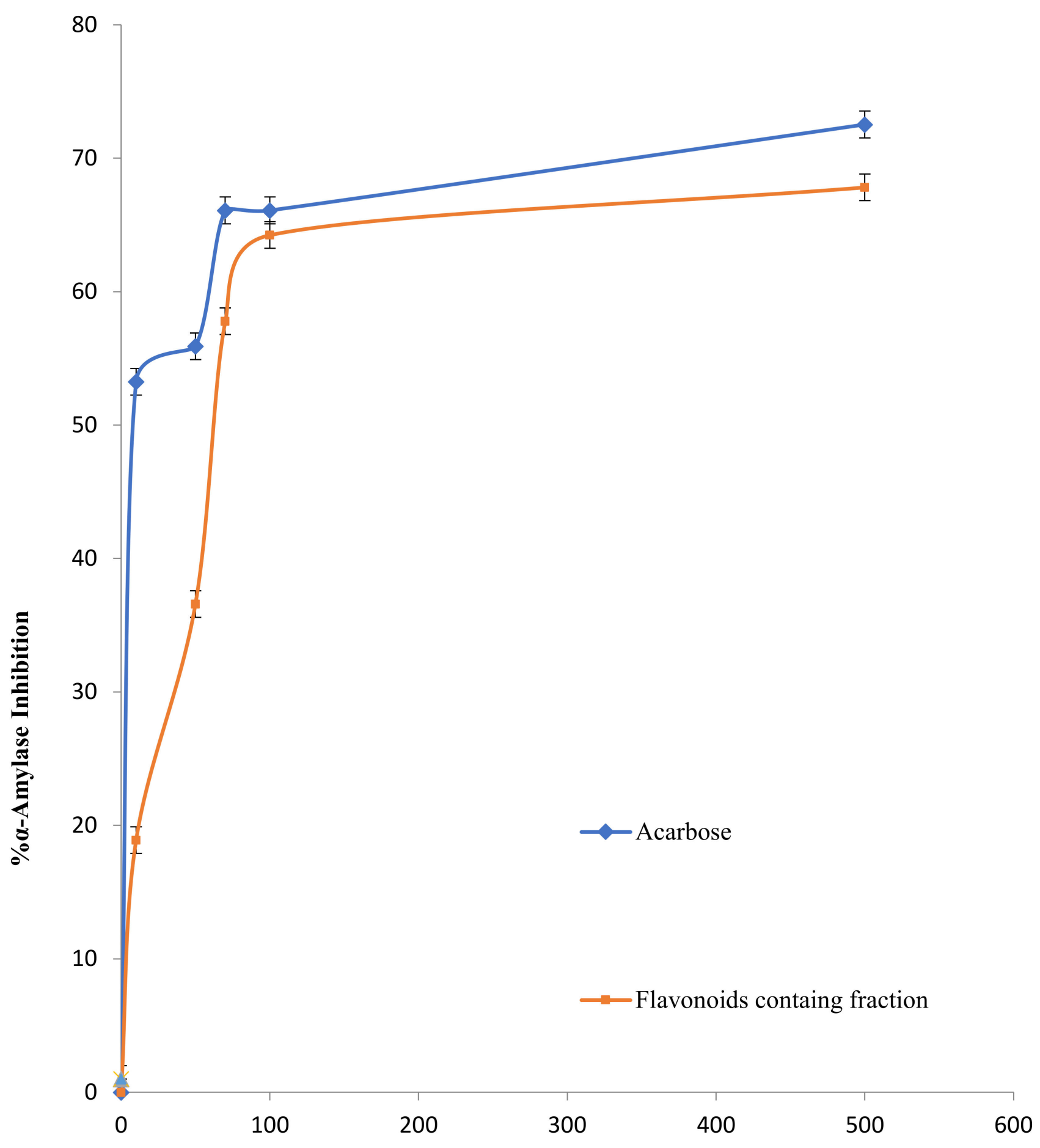

\section{Conc. $(\mu \mathrm{g} / \mathrm{mL})$}

Figure 4. $\alpha$-Amylase inhibitory activity of FFM and acarbose. 


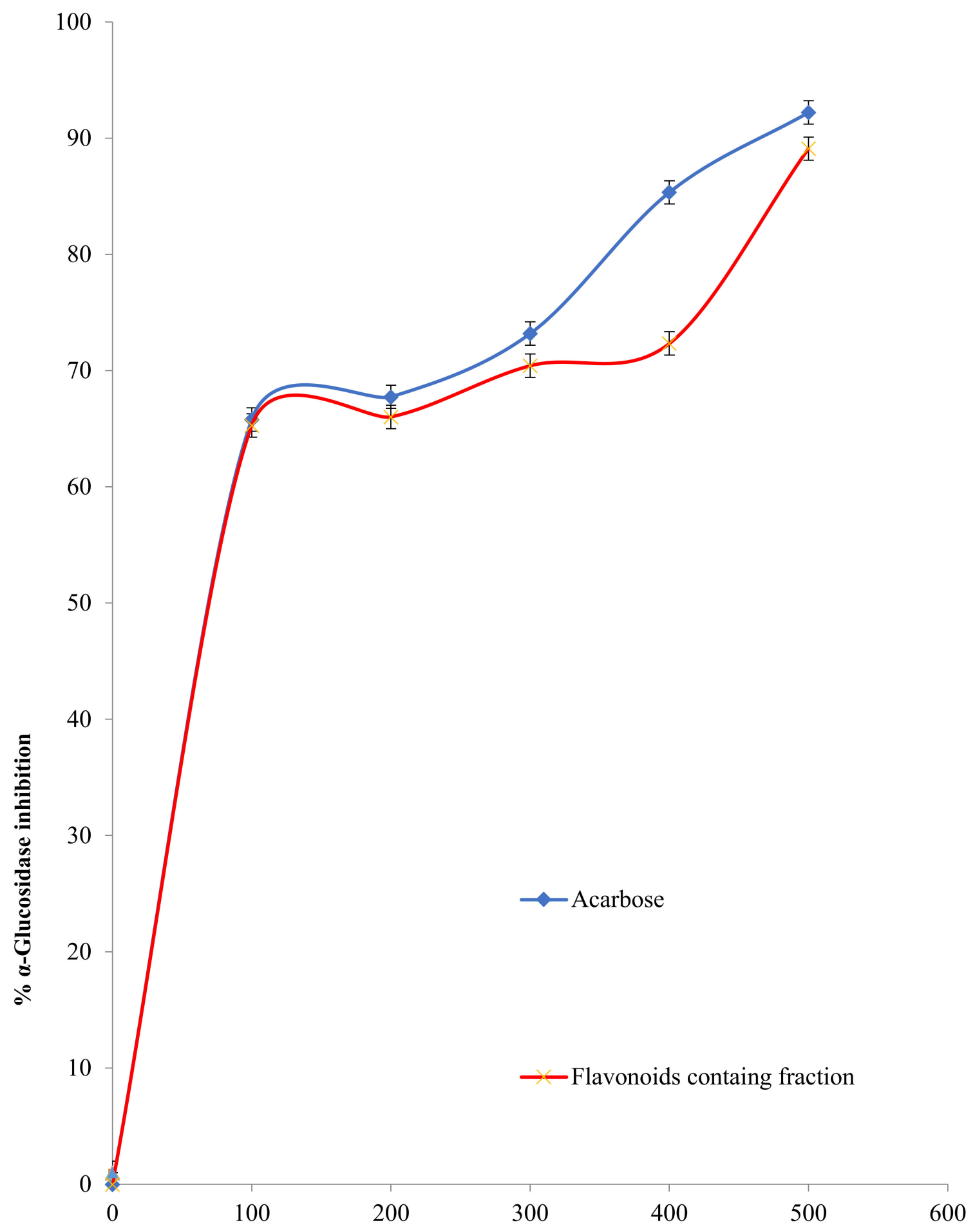

Conc. $(\mathrm{mg} / \mathrm{mL})$

Figure 5. $\alpha$-Glucosidase inhibition percentage of the FFM and acarbose. 


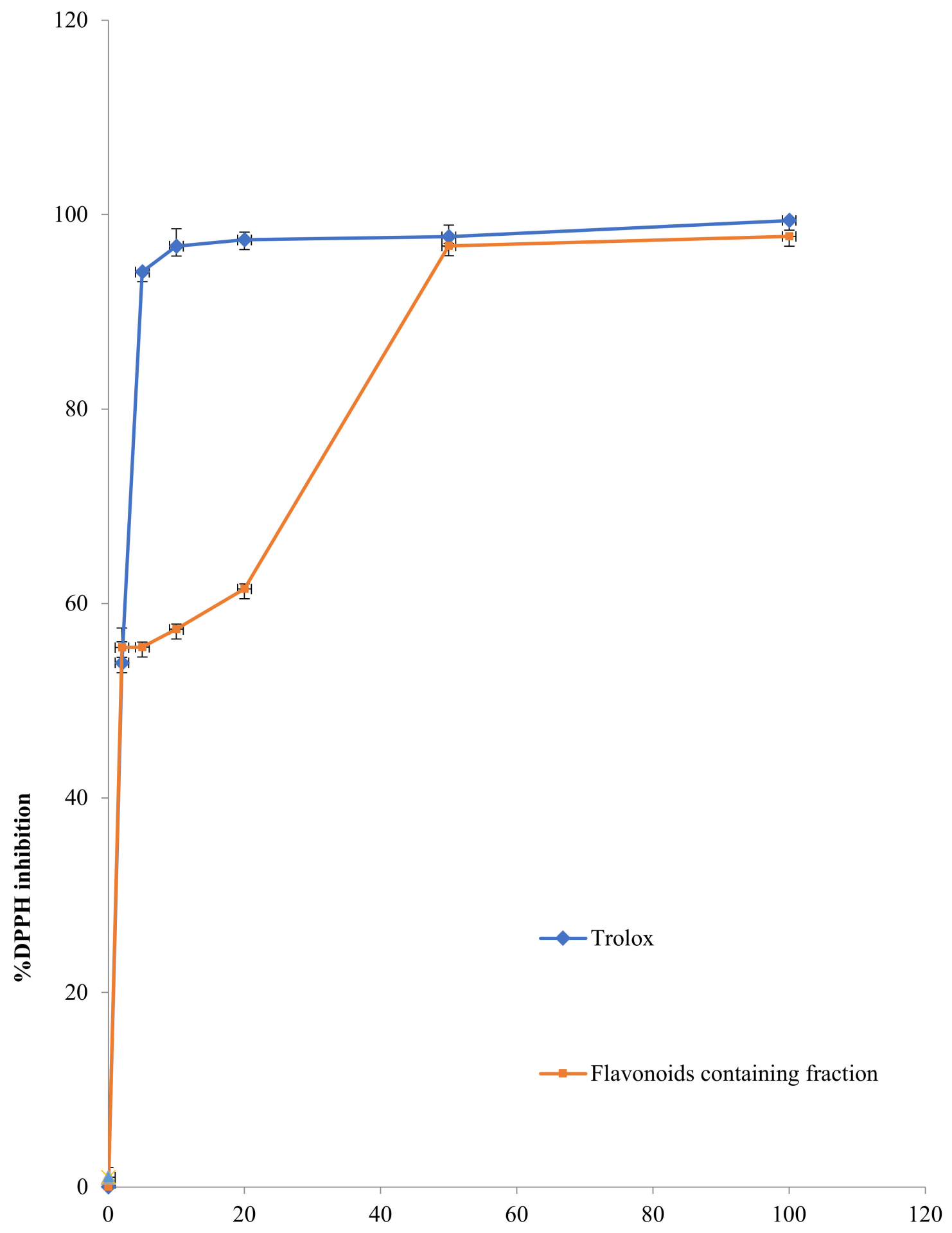

Conc. $(\mu \mathrm{g} / \mathrm{mL})$

Figure 6. DPPH inhibitory potentials by FFM and trolox. 


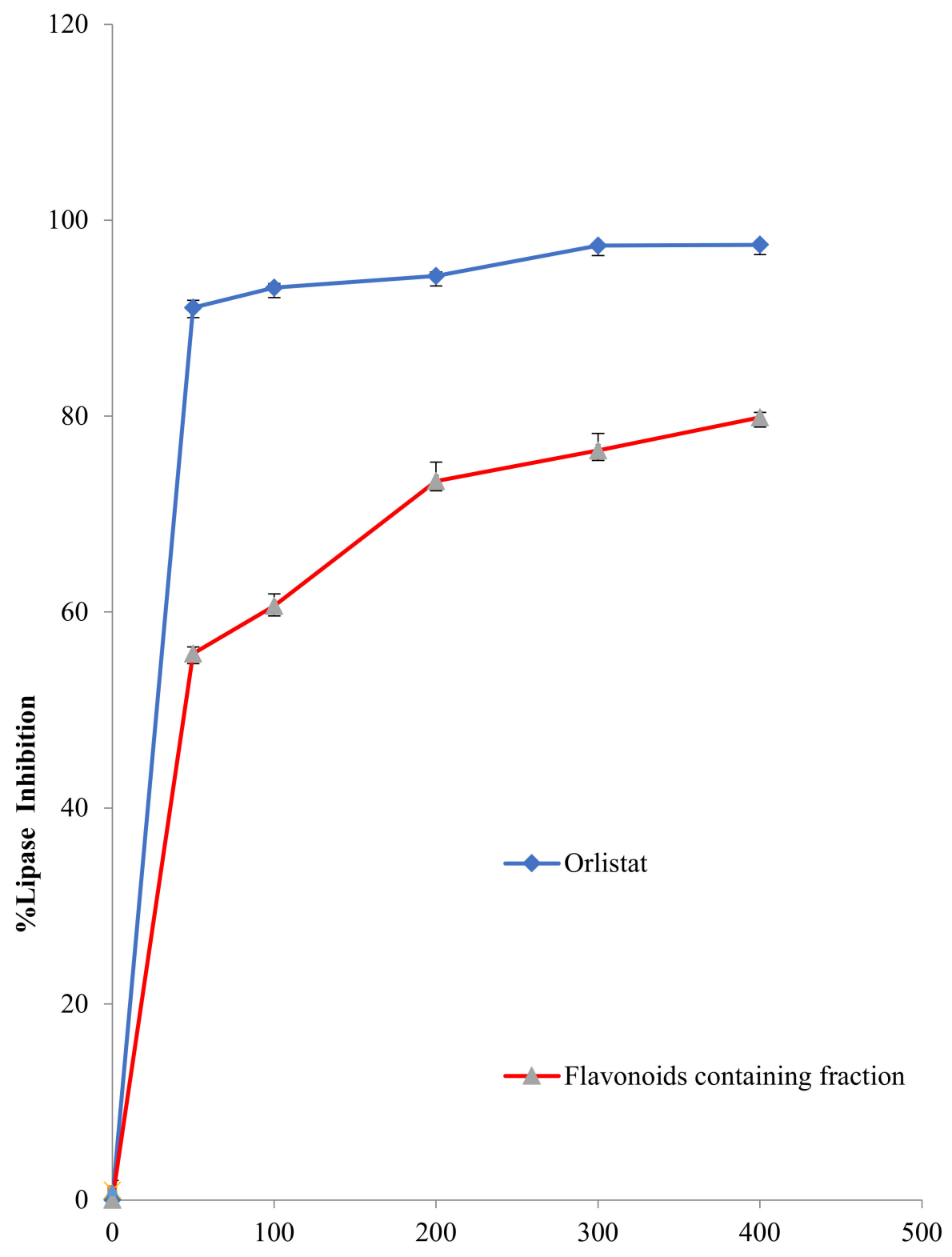

Conc. $(\mathbf{m g} / \mathbf{m L})$

Figure 7. The lipase inhibition percentage of FFM and orlistat.

\section{Discussion}

Plant extracts have been utilized in medicine, food preservation, medicines and cosmetics for hundreds of years. Since the time of Hippocrates (460-377 BC), they have been used to treat a wide range of human and animal ailments, including infectious, systemic and inflammatory ones [18]. The primary focus of many pharmaceutical experts is the discovery and screening of possible anti-diabetic, anti-obesity, antioxidant and antibacterial medications derived from natural ingredients. Flavonoids are a broad class of polyphenols that are produced by plants and are considered secondary metabolic products. They are chemically categorized into flavonols, flavones, flavanones, chalcones, isoflavones, aurones, anthocyanidins, flavan-3,4-diols and flavan-3-ols subgroups, each with its own set of physicochemical qualities, biological features and structural characteristics [19]. 


\subsection{Chemical Characterization}

Flavonoids are the primary active components of several therapeutic plants and foods, exerting a wide variety of pharmacological effects [20]. M. autumnalis has a long history of medicinal usage in the Arab world. Twenty-two alkaloids have previously been extracted and identified from the roots, leaves and flowers of $M$. autumnalis, while 55 chemicals representing the volatile components of $M$. autumnalis have been identified using capillary GC-MS [21]. Additionally, five coumarins have been isolated and identified from M. autumnalis roots, leaves and unripe fruits in Jordan Valley [11]. To the best of the authors' knowledge, no previous study has been conducted on the phytochemical components of $M$. autumnalis ripe fruits. Thus, the purpose of this work was to separate polyphenols, particularly flavonoids, from mature fruits of $M$. autumnalis methanolic extract. Four flavonoids (one flavones 2, two flavanols $\mathbf{1}$ and $\mathbf{3}$ and one flavanonol $\mathbf{4}$ ) were isolated utilizing a sequential flash column chromatography and preparative TLC.

Flavonoid 1 was obtained as a yellow powder with the molecular formula of $\mathrm{C}_{15} \mathrm{H}_{10} \mathrm{O}_{6}$ as shown from ESI-HRMS $[\mathrm{M}+\mathrm{H}]^{+}$at $m / z$ 287.0556. The ${ }^{13} \mathrm{C}-\mathrm{NMR}$ spectrum of $\mathbf{1}$ displayed resonance for all of the 15 carbons present in the molecule as indicated in the ${ }^{13} \mathrm{C}-\mathrm{NMR}$ (DEPT) (Figure S2). The ${ }^{1} \mathrm{H}$ - and ${ }^{13} \mathrm{C}-\mathrm{NMR}$ spectrum (Table 1, Figures S1 and S2) of 1 were similar to those reported in the literature for kaempferol $[22,23]$. Compound 2 was obtained as a pale yellow powder with a molecular peak at $m / z=287.0447[\mathrm{M}+\mathrm{H}]^{+}$, suggesting that its molecular formula was $\mathrm{C}_{15} \mathrm{H}_{10} \mathrm{O}_{6}$. The ${ }^{1} \mathrm{H}$ - and ${ }^{13} \mathrm{C}-\mathrm{NMR}$ spectra validated the skeleton as the luteolin 2 framework (Figures S5-S7) due to the presence of three ABX-type aromatic protons at $7.43\left(1 \mathrm{H}, \mathrm{dd}, J=8.2,2.2 \mathrm{~Hz}, \mathrm{H}-66^{\prime}\right), 7.40(1 \mathrm{H}, \mathrm{d}$, $\left.J=2.2 \mathrm{~Hz}, \mathrm{H}-2^{\prime}\right)$ and $6.89\left(1 \mathrm{H}, \mathrm{d}, J=8.2 \mathrm{~Hz}, \mathrm{H}^{\prime}\right)$, as well as the presence of four $\mathrm{OH}$ peaks. The HSQC and HMBC experiments supported the structure of 2 [20,22]. Thus, the structure of 2 was identified as 5,7,3', $4^{\prime}$-tetrahydroxyflavone (luteolin). Compound 3 was also obtained as a yellow amorphous powder. Its HR-ESI-MS spectra revealed a molecular peak at $m / z=319.0476[\mathrm{M}+\mathrm{H}]^{+}$, suggesting that it had the chemical formula $\mathrm{C}_{15} \mathrm{H}_{10} \mathrm{O}_{8}$. The ${ }^{1} \mathrm{H}-\mathrm{NMR}$ spectra revealed that 3 was a flavonol with six $\mathrm{OH}$ peaks and four aromatic proton peaks (Figure S8). When ${ }^{1} \mathrm{H}$ - and ${ }^{13} \mathrm{C}-\mathrm{NMR}$ (Table 1, Figures S8 and S9) data were compared with published data [22,24], the chemical structure of $\mathbf{3}$ was discovered to be a myricetin skeleton.

Compound 4 was isolated as a pale yellow solid and its chemical formula was established as $\mathrm{C}_{15} \mathrm{H}_{12} \mathrm{O}_{7}$ based on ESI-HRMS $m / z$ 305.0531 $[\mathrm{M}+\mathrm{H}]^{+}$and NMR spectral data. Compound 4 had 15 carbon atoms, including 8 quaternary carbons and 7 methine carbons, according to the DEPT and HMQC spectra (Figures S11 and S12). The presence of flavanonol framework was evident from the ${ }^{1} \mathrm{H}$ NMR spectrum (Table 1, Figure S10), which displayed the presence of one-proton doublet of a doublet at $4.51(J=11.2,5.9 \mathrm{~Hz})$ and a doublet at $4.99(\mathrm{~J}=11.2 \mathrm{~Hz})$ corresponding to $\mathrm{H}-3$ and $\mathrm{H}-2$, respectively. The carbon resonances at 72.0, 83.5 and 198.3, designated C-3, C-2 and C-4 of the flavanonol C-ring, respectively, confirmed this identification. $\mathrm{H}-2$ and $\mathrm{H}-3$ were trans, as shown by their coupling constants of $11.2 \mathrm{~Hz}$. The ${ }^{1} \mathrm{H}-\mathrm{NMR}$ spectrum (Figure S10) revealed the existence of aromatic signals at 5.89 and 5.94, corresponding to $\mathrm{H}-6$ and $\mathrm{H}-8$, respectively, and a multiplet in the area 6.74 , corresponding to $\mathrm{H}-5^{\prime}, 6^{\prime} .{ }^{1} \mathrm{H}$ - and ${ }^{13} \mathrm{C}-\mathrm{NMR}$ spectra, further revealed the presence of five hydroxyl groups, of which the $3-\mathrm{OH}$ hydroxyl resonated at $\delta_{\mathrm{H}}$ 5.74. In the HMQC spectrum (Figure S12), the proton signal at 4.51 (H-3) showed one bond correlation with the carbon signal at 72.0. The proton signal at $\delta_{\mathrm{H}} 4.99(\mathrm{H}-2)$ had long-range correlations with carbon signals at $\delta_{\mathrm{C}} 128.5$ and 72.0, showing carbon signals at $\delta_{\mathrm{C}} 128.5$ and 72.0 to be due to $C-1^{\prime}$ and $C-3$, respectively (Figure S14). All of these data matched those reported in the literature, confirming the identity of compound 4 as taxifolin [25].

\subsection{Antidiabetic Effects}

Diabetes mellitus is a metabolic disorder characterized by the failure of insulin secretion by pancreatic $\beta$-cells, or poor responses of cells to insulin. Diabetes could lead to long-term complications such as microangiopathy, neuropathy and retinopathy. Acarbose, 
a synthetic antidiabetic used to suppress the activity of $\alpha$-amylase and $\alpha$-glucosidase in the small intestine, is linked with a number of adverse effects, including intestinal pneumatosis, abdominal distention, gas and diarrhea [26]. Additionally, some synthetic antidiabetic medications have severe adverse, and in some cases fatal, side effects. As a result, scientists have focused their research during the last two decades on natural products such as flavonoids as potential substitutes for acarbose and other antidiabetic medications.

\subsubsection{FFM Effects on GLUT4 Translocation}

Normal glucose metabolism, crucial in maintaining homeostasis, is regulated by two primary hormones, namely insulin and glucagon. Following hydrolysis of starch in the upper gastrointestinal tract, the formed monosaccharides are absorbed through glucose transporters (GLUT) into the bloodstream. Fourteen GLUT proteins, including GLUT 1-12, myoinositol transporter (HMIT) and GLUT 14, are expressed in humans [27]. Both glucose and insulin are potent enhancers of hippocampal memory processes and it has been suggested that insulin's cognitive effects may occur via upregulation in GLUT4-mediated glucose uptake [28]. Indeed, GLUT4 is responsible for the majority of the circulating blood glucose clearance and uptake into skeletal muscle, liver and fat cells. GLUT4 is insulinsensitive and upon insulin stimulation, GLUT4 is translocated to the PM from intracellular vesicular [28]. However, this process is diminished in insulin resistance and diabetes type 2.

The effect of FFM on GLUT4 translocation to the PM in the L6 skeletal muscle cell line was examined in this work. The results indicate that FFM dramatically increased the amount of GLUT4 in the PM in both the presence and the absence of insulin. These findings suggest that FFM may include anti-diabetic chemicals. Flavonoids have been shown to have anti-diabetic action via distinct mechanisms. Certain flavonoids have been shown to enhance glucose uptake by hepatocytes and myocytes [29]. The stimulatory effect of the four flavonoids mixture on GLUT4 translocation reported here is attributed to kaempferol and myricetin. Both have been shown to improve glucose elimination in diabetic rats fed a high-fat diet [30,31].

Most notably, kaempferol reduced GLUT4 and AMPK expression in muscle and adipose tissue in obese mice while reversing the high-fat diet. In obese diabetic mice, kaempferol therapy improved hyperglycemia and glucose tolerance [29]. These findings, together with our own, imply that kaempferol's anti-diabetic action is mediated in part by increased GLUT4 translocation and activation.

\subsubsection{Carbohydrates Metabolic Enzymes}

The findings of this study demonstrated that FFM has potent $\alpha$-amylase and $\alpha$ glucosidase activity. The FFM displayed potent $\alpha$-amylase inhibitory action with an $\mathrm{IC}_{50}$ value of $72.44 \pm 0.89 \mu \mathrm{g} / \mathrm{mL}$, lower than the commercial anti-diabetic medication acarbose $\left(\mathrm{IC}_{50}=28.18 \pm 1.22 \mu \mathrm{g} / \mathrm{mL}\right)$. These findings are consistent with those published earlier by Proenca et al., who used a microanalysis screening method to examine the capacity of 40 structurally similar flavonoids to inhibit $\alpha$-amylase activity [32]. It was reported that kaempferol and luteolin and myricetin inhibited $\alpha$-amylase with an $\mathrm{IC}_{50}$ value of $118 \pm 7$, $78 \pm 3$ and $107 \pm 6 \mu \mathrm{M}$. Moreover, this plant fraction displayed powerful $\alpha$-glucosidase inhibitory activity with an $\mathrm{IC}_{50}$ value of $39.81 \pm 0.74 \mu \mathrm{g} / \mathrm{mL}$, which is comparable to that of acarbose $\left(\mathrm{IC}_{50}=37.15 \pm 0.33 \mu \mathrm{g} / \mathrm{mL}\right)$.

These findings add to prior research indicating that natural polyphenols, particularly flavonoids, can inhibit the activity of carbohydrate-hydrolyzing enzymes such as $\alpha$-amylase and $\alpha$-glucosidase [33]. A review article concerning pharmacokinetic effects and the structure-activity relationship (SAR) between flavonoids and $\alpha$-amylase and $\alpha$ glucosidase inhibitory activities highlighted that various flavonoids displayed higher $\alpha$-glucosidase inhibitory activity than acarbose [34,35]. Two binding manners between enzymes and flavonoids have been detected: (i) flavonoids bind directly to amino acid residues in the active sites of enzymes and exclude the binding of substrate; (ii) flavonoids 
can interact with amino acid residues near the active site and close the channel to the active center [35].

\subsection{DPPH Scavenging Effect of FFM}

As a result of various endogenous systems and exposure to various physico-chemical conditions, or pathological states, our bodies produce reactive oxygen and reactive nitrogen species, known as radicals. For proper physiological function, a balance between antioxidants and free radicals is required. Oxidative stress occurs when free radicals overwhelm the body's ability to regulate them. Free radicals alter lipids, proteins and DNA, resulting in a wide range of human diseases. Hence consumption of antioxidants' rich diet can assist in coping with this oxidative stress [36,37]. Our results revealed that FFM extract displayed free radical scavenging character with $\mathrm{IC}_{50}$ values of $5.37 \pm 0.41 \mu \mathrm{g} / \mathrm{mL}$, being comparable with the standard antioxidant trolox $\left(\mathrm{IC}_{50}=2.23 \pm 1.23 \mu \mathrm{g} / \mathrm{mL}\right)$. Previous studies demonstrated that flavonoids and other polyphenols are able to scavenge the DPPH free radicals by donating their hydrogen [38]. This result is in accordance with that obtained in a study conducted by Sim et al., where he reported that kaempferol, luteolin, and myricetin displayed DPPH radical scavenging activities with $\mathrm{IC}_{50}$ values 12,5 , and $4 \mu \mathrm{M}$ [39].

\subsection{Anti-Lipase Activity}

Obesity and overweight are chronic metabolic disorders caused by an imbalance of energy expenditure and intake. They are major risk factors for cancer as well as cardiovascular, metabolic and endocrine diseases [40]. The lipolytic pancreatic lipase enzyme is synthesized and secreted by the pancreas, plays a functional role in the digestion of fats and is responsible for the hydrolysis of $50-70 \%$ of total dietary lipids. Determination of the anti-lipase effects is one of the most widely investigated mechanisms for evaluating the efficiency of synthetic and natural products as anti-obesity medications [41]. The current study showed that the FFM has potent porcine pancreatic lipase inhibitory activity with an $\mathrm{IC}_{50}$ value of $39.81 \pm 1.23 \mu \mathrm{g} / \mathrm{mL}$, compared with that of orlistat $\left(\mathrm{IC}_{50}=12.56 \pm 0.35 \mu \mathrm{g} / \mathrm{mL}\right)$. Shimura et al. reported that kaempferol, luteolin and myricetin inhibited lipase activity with $\mathrm{IC}_{50}$ of $0.72,2.03$ and $2.54 \mu \mathrm{g} / \mathrm{mL}$, respectively [42].

In fact, orlistat is a potent inhibitor of pancreatic lipase enzyme produced from Streptomyces toxytricini bacteria. This clinically approved medication is intended for the treatment of obesity and overweight by decreasing the digestion of lipids [43].

\subsection{Antimicrobial Activity}

The microdilution assay was utilized to assess the FFM's antimicrobial activity. The results showed that FFM has potent antibacterial activity against the K. pneumoniae strain, with a MIC value of $0.135 \pm 0.01 \mu \mathrm{g} / \mathrm{mL}$, being comparable with the reference drug ciprofloxacin $(\mathrm{MIC}=0.13 \pm 0.02 \mu \mathrm{g} / \mathrm{mL})$ and higher than ampicillin $(\mathrm{MIC}=1 \pm 0.02 \mu \mathrm{g} / \mathrm{mL})$. Furthermore, FFM extract showed higher antibacterial activity against $S$. aureus, E. coli and MRSA with MIC values of $1.5 \pm 0.07,2.25 \pm 0.07$ and $25 \pm 1.01 \mu \mathrm{g} / \mathrm{mL}$, respectively, than the reference drug ampicillin $(\mathrm{MIC}=3.12 \pm 0.02,3.12 \pm 0.23$, and $60.5 \pm 0.71 \mu \mathrm{g} / \mathrm{mL}$, respectively). It exhibits antibacterial activity against $P$. aeruginosa with a MIC of $12.5 \pm 0.98 \mu \mathrm{g}$, comparable to ampicillin. The FFM showed potent antifungal activity against C. albicans, compared with the commercial antifungal drug fluconazole with MIC values of $6.25 \pm 0.48$ and $1.56 \pm 0.01 \mu \mathrm{g} / \mathrm{mL}$, respectively. Finally, this plant fraction exhibited a weak anti-mold activity (E. floccosum) with a MIC value of $12.5 \pm 0.88 \mu \mathrm{g} / \mathrm{mL}$, compared with fluconazole, which was used as a positive control and has a MIC value of $0.78 \mu \mathrm{g} / \mathrm{mL}$.

Obeidat demonstrated that M. autumnalis fruits' ethanolic extract displayed potential antimicrobial activity against E. coli, P. aeroginosa, MRSA and C. albicans [44].

Extracts of numerous medicinal plants encompassing flavonoids have been previously stated to possess antimicrobial activity $[45,46]$. Flavonoids are well established as antimicrobial agents for a wide spectrum of microbial strains. However, with the rising incidence of microbial resistance to antibiotics, flavonoids have become fascinating targets 
due to their usefulness as powerful alternatives to antibiotics. The presence of hydroxyl groups at certain places in flavonoids structures, particularly on aromatic rings, promotes antibacterial action. Hydrophobic substituents such as alkyl chains, alkylamino chains, prenyl groups and oxygen or nitrogen-containing heterocyclic sections improved the antibacterial activity of all flavonoids [47]. Flavonoids have a variety of modes of action against microbial species, including porin inhibition on the cell membrane, adhesion and biofilm development, energy metabolism, cytoplasmic membrane function and nucleic acid synthesis. Furthermore, flavonoids can alter the permeability of microbial cell membranes and reduce pathogenicity [48].

To the best of the authors' knowledge, this is the first study that has looked at the chemical content and biological activity of M. autumnalis fruits. More research is needed to establish these putative pharmacological characteristics of the FFM extract of M. autumnalis in order to assess its impact in animal models and build suitable pharmaceuticals or food supplement formulations from this fraction.

\section{Materials and Methods}

\subsection{Chemicals, Reagents and Instruments}

The rat L6 muscle cell line and stably expressing myc-tagged GLUT4 (L6-GLUT4myc cells) were obtained from (Kerafast, Boston, MA, USA). Fetal bovine serum, modified Eagle's medium ( $\alpha$-MEM), standard culture medium and all of the other tissue culture reagents were purchased from (Biological Industries, Beit Haemek, Israel). Horseradish peroxidase (HRP)-conjugated goat anti-rabbit antibodies were obtained from (Promega, Madison, WI, USA). Polyclonal anti-myc (A-14), the 3-(4,5-dimethylthiazol-2-yl)-2,5-diphenyl tetrazolium bromide (MTT) reagent, methoxyamine hydrochloride, pyridine, $\mathrm{N}$-methyl- $\mathrm{N}$ (trimethylsilyl)-trifluoroacetamide (MSTFA) and other standard chemicals were purchased from (Sigma-Aldrich, St. Louis, MO, USA).

All of the solvents used were HPLC-grade and acquired from (Alfa Aesar, Heysham, Lancashire, England). Tris- $\mathrm{HCl}$, silica gel 60 GF254 thin-layer chromatography, silica gel (100-200 and 200-300 mesh) for column chromatography, porcine pancreatic amylase and lipase enzymes were acquired from (Sigma-Aldrich, Burlington, MA, USA). Corn starch was purchased from (Alzahra Company, Nablus, Palestine). Ampicillin, 3,5-dinitrosalicylic acid, ciprofloxacin and orlistat were acquired from (Sigma-Aldrich, Anekal Taluk, Bangalore, India). Acarbose, $\alpha$-glucosidase, phosphate buffer, $\mathrm{Na}_{2} \mathrm{CO}_{3}$, 2,2-diphenyl-1-picrylhydrazyl (DPPH) and trolox were purchased from Sigma-Aldrich (Taufkirchen, Germany). Finally, Mueller-Hinton broth, fluconazole, Sabouraud dextrose agar and dimethyl sulphoxide (DMSO) were acquired from Himedia (Mumbai, Maharashtra, India).

The ${ }^{1} \mathrm{H}$ - and ${ }^{13} \mathrm{C}-\mathrm{NMR}$ spectra were obtained using a Bruker AV-400 instrument and DMSO- $\mathrm{d}_{6}$ as a solvent. Spectrophotometer (Jenway 7315, Staffordshire, England), microtiter plate reader (Anthos, USA), stir-mixer (Tuttnauer, Jerusalem, Palestine), weighing scale (Adam Equipment Inc., Oxford, CT, USA), multichannel micro-pipet (Eppendorf, Hamburg, Germany(, shaker incubator apparatus (Memmert incurboration, Büchenbach, Germany), sterile syringe filter hydrophobic (PTFE, Yangtze River Delta, China) and an incubator with $\mathrm{CO}_{2}$ (Tuttnauer, Jerusalem, Palestine) were used to complete the current study; the microplate reader was from Anthos, Biochrom (Cambridge, UK).

\subsection{Plant Collection and Preparation}

In May 2020, the golden mature fruits of M. autumnalis were harvested in the Nablus highlands of Palestine. The plant was validated in the Herbal Products Laboratory at An-Najah National University and deposited in the same laboratory under the voucher specimen code Pharm-PCT-1509. M. autumnalis fruits were cleaned with distilled water and dried in the shade at room temperature $\left(25 \pm 2{ }^{\circ} \mathrm{C}\right)$. After four weeks, the total dry fruits were finely crushed and kept in a tightly sealed glass jar for future use. 


\subsection{Extraction and Isolation of Compounds}

M. autumnalis fruit powder $(200 \mathrm{~g})$ was macerated with methanol $(0.5 \mathrm{~L})$, and the suspension was agitated at $35^{\circ} \mathrm{C}$ for $24 \mathrm{~h}$. The resultant extract was filtered, and the residual solid was extracted again with $0.5 \mathrm{~L}$ of methanol under the same conditions. Methanol was removed under reduced pressure to offer dark green sticky oil. Water $(50 \mathrm{~mL})$ was added to the concentrated green extract before extracting it with pentane to remove lipids, waxes and nonpolar chemicals and ethyl acetate to extract the flavonoids and other polyphenols. The biological effects of the ethyl acetate fraction of the methanolic extract of $M$. autumnalis fruits were studied.

The ethyl acetate extract ( $3 \mathrm{~g}$ ) was subjected to silica gel column chromatography utilizing gradient dichloromethane-EtOAc (10:0-1:1) to obtain four fractions. Fraction 2 $(0.687 \mathrm{~g})$ was subjected to silica gel column chromatography employing gradient elution (hexane: acetone 10:0-10:1) to give compound 1 (6 mg). Fraction 3 (0.58 g) was subjected to silica gel column chromatography eluted with hexane-acetone (95:5-9:10) to obtain two fractions. Fraction $3 a$ was subjected repeatedly to silica gel column chromatography eluted with hexane-acetone (95:5) and was finally purified by a preparative thin-layer chromatography column eluted with $\mathrm{CH}_{2} \mathrm{Cl}_{2}$-EOAc (7:3) to give compound $2(6 \mathrm{mg})$. Fraction $3 \mathrm{~b}$ was subjected to silica gel column chromatography using gradient elution with hexane-acetone (99:1-90:10) followed by preparative TLC to give compound $4(7.6 \mathrm{mg})$. Fraction $4(0.72 \mathrm{~g})$ was subjected to repeated silica gel column chromatography using gradient elution $\mathrm{CH}_{2} \mathrm{Cl}_{2}$-EtOAc (9:1-6:4) led to the isolation of compound 3 (4.3 mg) [23].

\subsection{Biological Method}

\subsubsection{Cell Growth and Treatment}

Cells from the rat L6 muscle cell line, stably expressing myc-tagged GLUT4 (L6GLUT4myc), obtained from Kerafast (Boston, MA, USA), were maintained under an atmosphere of $95 \%$ air and $5 \% \mathrm{CO}_{2}$ in $\alpha$-MEM supplemented with $10 \%$ fetal calf serum (FCS), $100 \mathrm{U} / \mathrm{mL}$ penicillin and $0.1 \mathrm{mg} / \mathrm{mL}$ streptomycin.

\subsubsection{Cytotoxicity}

The cellular metabolic activity was assessed as an indication of cell viability using the MTT test methodology devised by [49]. This procedure relies on the reduction of the yellow-colored 3-(4,5-dimethylthiazol-2-yl)-2,5-diphenyl tetrazolium bromide (MTT) by cellular enzymes to the purple formazan. L6-GLUT4myc cells were seeded at a density of $2 \times 10^{4}$ cells/well in 96-well plates with $100 \mu \mathrm{L}$ of culture media in each well. After $24 \mathrm{~h}$, FFM was administered at increasing doses $(0-1 \mathrm{mg} / \mathrm{mL})$ for $20 \mathrm{~h}$. The cell media was then changed with $100 \mu \mathrm{L}$ of new medium/well containing MTT $(0.5 \mathrm{mg} / \mathrm{mL})$ and cultured for $4 \mathrm{~h}$ in the cell's incubator in the dark. The supernatant was withdrawn from each well, and $100 \mu \mathrm{L}$ of isopropanol $/ \mathrm{HCl}(1 \mathrm{mM} \mathrm{HCl}$ in $100 \%$ isopropanol) was added. Using a microtiter plate reader, the absorbance at $620 \mathrm{~nm}$ was measured. A microtiter plate reader was used to detect absorbance at $620 \mathrm{~nm}$. To serve as controls, two wells on each plate were left unfilled. All of the experiments were conducted three times [50]. To illustrate the effect of the FFM on cell viability, the following formula was used:

$$
\text { Percent viability }=\left(\frac{\mathrm{A} 620 \mathrm{~nm} \text { of plant extract treated sample }}{\mathrm{A} 620 \mathrm{~nm} \text { of nontreated sample }}\right) \times 100
$$

\subsubsection{Determination of Surface GLUT4myc}

Surface myc-tagged GLUT-4 was assessed in intact, non-permeabilized cells using an anti-myc antibody followed by a secondary antibody coupled to horseradish peroxidase, as previously described [51]. Cells were seeded in 24-well plates for $24 \mathrm{~h}$ before the plant extracts were added for $20 \mathrm{~h}$. The cells were then serum-starved for $3 \mathrm{~h}$ before being treated for $20 \mathrm{~min}$ with or without $100 \mathrm{nM}$ insulin and rinsed twice with ice-cold PBS. The cells were fixed for $10 \mathrm{~min}$ in 3\% paraformaldehyde, incubated for $10 \mathrm{~min}$ in $0.1 \mathrm{M}$ glycine, 
blocked for $10 \mathrm{~min}$ in 3\% (v/v) goat serum, then reacted with polyclonal anti-myc antibody (1:200) for $1 \mathrm{~h}$ at $4{ }^{\circ} \mathrm{C}$ before being washed 10 times in PBS. Following that, cells were incubated for $1 \mathrm{~h}$ at $4{ }^{\circ} \mathrm{C}$ with horseradish peroxidase-bound goat anti-rabbit secondary antibody (1:1000) before being washed 15 times with PBS. Cells were then treated with $1 \mathrm{~mL}$ of phenylenediamine dihydrochloride reagent and allowed to develop in the linear range for 20-30 min in the dark at room temperature. The reaction was quenched by the addition of $1 \mathrm{~mL}$ of $3 \mathrm{~N} \mathrm{HCl}$ to each well. Supernatants were collected, and absorbance at $492 \mathrm{~nm}$ was measured. All of the results were subtracted from the background absorbance obtained in the absence of anti-myc antibodies.

\subsection{4. $\alpha$-Amylase Inhibitory Method}

$25 \mathrm{mg}$ of FFM was dissolved in 10\% DMSO (25 mL). The solution was diluted using $0.02 \mathrm{M}$ sodium phosphate buffer ( $\mathrm{pH}$ 6.9) to generate the following dilutions: $10,50,70$, 100 and $50 \mu \mathrm{g} / \mathrm{mL}$. In parallel, a working solution of the $\alpha$-amylases enzyme ( 2 units $/ \mathrm{mL}$ ) was made by combining $12.5 \mathrm{mg}$ of this enzyme powder with a few drops of $10 \% \mathrm{DMSO}$, and a buffer solution was added to achieve $100 \mathrm{~mL}$. The starch solution was made by dissolving $1 \mathrm{~g}$ of corn starch in distilled water $(100 \mathrm{~mL})$. A combination of $200 \mu \mathrm{L}$ of FFM stock solution, $200 \mu \mathrm{L}$ of $\alpha$-amylase stock solution and $200 \mu \mathrm{L}$ of corn starch solution was incubated in a water bath at $30{ }^{\circ} \mathrm{C}$ for $15 \mathrm{~min}$. In addition, 3,5-dinitrosalicylic acid was added to the mixture and cooked for $10 \mathrm{~min}$ in a water bath at $85-90{ }^{\circ} \mathrm{C}$. After allowing the mixture to cool to room temperature, $5 \mathrm{~mL}$ of distilled water was added. The blank solution was created by substituting the plant portion with $200 \mu \mathrm{L}$ of the buffer. Acarbose was employed as a positive control, and absorbance was measured at $540 \mathrm{~nm}$ using a Spectrophotometer (UV-Vis). The $\alpha$-amylase inhibitory concentrations were estimated using the following equation:

$$
\left.\mathrm{I}(\%)=\left[\mathrm{ABS}_{\text {blank }}-\mathrm{ABS}_{\text {test }}\right] /\left[\mathrm{ABS}_{\text {blank }}\right]\right) \times 100 \%
$$

where I (\%) is the $\alpha$-amylase inhibitory percentage [52].

\subsection{5. $\alpha$-Glucosidase Inhibitory Activity}

The stock solution was prepared by dissolving a portion of the FFM (1 mg) in phosphate buffer $(1 \mathrm{~mL})$. The resulting solution was diluted with phosphate buffer to achieve different concentrations $(100,200,300,400$ and $500 \mu \mathrm{g} / \mathrm{mL})$. Twenty microliters of the stock solution and $\alpha$-glucosidase solution ( 1 unit $/ \mathrm{mL}$ ) were then mixed with $50 \mu \mathrm{L}$ of phosphate buffer and incubated in a water bath at $37^{\circ} \mathrm{C}$ for $15 \mathrm{~min}$. Thereafter, $20 \mu \mathrm{L}$ of P-NPG solution was added to the mixture and incubated for $20 \mathrm{~min}$ at $37^{\circ} \mathrm{C}$ before terminating the reaction with $50 \mu \mathrm{L}$ of $0.1 \mathrm{M} \mathrm{Na}_{2} \mathrm{CO}_{3}$. The blank solution was prepared by replacing the FFM solution with phosphate buffer. Acarbose was employed as a positive control, and absorbance was measured at $405 \mathrm{~nm}$ using a UV-Vis spectrophotometer. The $\alpha$-glucosidase inhibitory activity was calculated using the following formula:

$$
\left.\mathrm{I}(\%)=\left[\mathrm{ABS}_{\text {blank }}-\mathrm{ABS}_{\text {test }}\right] /\left[\mathrm{ABS}_{\text {blank }}\right]\right) \times 100 \%
$$

where I (\%) is the percentage inhibition of $\alpha$-glucosidase [53].

\subsubsection{DPPH Scavenging Activity}

A $1 \mathrm{mg} / \mathrm{mL}$ working solution was made by dissolving $100 \mathrm{mg}$ of FFM in $100 \mathrm{~mL}$ of methanol, which was then diluted with methanol to yield serial concentrations (2, 5, 10, 20, 50 and $100 \mu \mathrm{g} / \mathrm{mL})$. Methanol $(1 \mathrm{~mL})$ was added to the FFM stock solution $(1 \mathrm{~mL})$, followed by DPPH solution $(1 \mathrm{~mL})$, and the combination was incubated for $30 \mathrm{~min}$ at room temperature under the light exclusion. The blank solution was prepared by replacing the plant fraction solution with methanol. Trolox was employed as a positive control, and absorbance was measured at $517 \mathrm{~nm}$ using a UV-Vis spectrophotometer and 
compared to the positive control. The DPPH scavenging activity was calculated using the following equation:

$$
\left.\mathrm{I}(\%)=\left[\mathrm{ABS}_{\text {blank }}-\mathrm{ABS}_{\text {test }}\right] /\left[\mathrm{ABS}_{\text {blank }}\right]\right) \times 100 \%
$$

where I (\%) is the percentage of DPPH scavenging activity [54].

\subsubsection{Porcine Pancreatic Lipase Enzyme Inhibitory Assay}

In a beaker, $100 \mathrm{mg}$ of FFM was dissolved in $10 \%$ DMSO to achieve a series of concentrations $(50,100,200,300$ and $400 \mu \mathrm{g} / \mathrm{mL})$. Right before use, a lipase enzyme stock solution $(1 \mathrm{mg} / \mathrm{mL})$ was produced by dissolving lipase enzyme powder $(25 \mathrm{mg})$ in 10\% DMSO (25 mL). The p-nitrophenyl butyrate (PNPB) stock solution was prepared by dissolving PNPB (20.9 mg) in acetonitrile $(2 \mathrm{~mL})$. Then, $0.2 \mathrm{~mL}$ of each of the FFM serial dilutions was mixed with lipase enzyme stock solution $(0.1 \mathrm{~mL})$ and Tris- $\mathrm{HCl}$ solution was added to the mixture to bring the total volume to $1 \mathrm{~mL}$. After $15 \mathrm{~min}$ of incubation at $37^{\circ} \mathrm{C}$ in a water bath, a $100 \mu \mathrm{L}$ of PNPB solution was added and the mixture was incubated for $30 \mathrm{~min}$ at $37^{\circ} \mathrm{C}$. The blank solution was prepared by mixing $100 \mu \mathrm{L}$ of the lipase enzyme solution $(1 \mathrm{mg} / \mathrm{mL})$ with a Tris- $\mathrm{HCl}$ solution $(0.9 \mathrm{~mL})$. Orlistat was used as a positive control. The absorbance was measured using a spectrophotometer (UV-Vis) at $405 \mathrm{~nm}$. Lipase enzyme inhibitory percentage was calculated employing the next equation [41]:

$$
\left.\mathrm{I}(\%)=\left[\mathrm{ABS}_{\text {blank }}-\mathrm{ABS}_{\text {test }}\right] /\left[\mathrm{ABS}_{\text {blank }}\right]\right) \times 100 \%
$$

\subsubsection{Antimicrobial Activity}

The bacterial and fungal strains used in the current investigation were obtained from the American Type Culture Collection (ATCC) and clinical isolates. Staphylococcus aureus (ATCC 25923), Enterococcus faecium (ATCC 700221) and Methicillin-Resistant Staphylococcus aureus (clinical isolate) belong to Gram-positive strains. In addition to Shigella sonnie (ATCC 25931), Pseudomonas aeruginosa (ATCC 27853), Klebsiella pneumoniae (ATCC 13883) and Escherichia coli (ATCC 25922), which are classified as Gram-negative species.

The effect of the FFM against the fungal strains including Epidermatophyton floccosum (ATCC 10231) and Candida albicans (ATCC 90028) were also evaluated. The antimicrobial activity of the FFM against fungal and bacterial strains was evaluated using the microdilution technique. Mueller-Hinton broth $\left(8.8 \mathrm{~g}\right.$ ) was autoclaved and kept at $4{ }^{\circ} \mathrm{C}$ after $400 \mathrm{~mL}$ of distilled water was added. The extract was first dissolved in sterile distilled water at a concentration of $1 \mathrm{mg} / \mathrm{mL}$. In each well of the 96-well microdilution plate, $100 \mu \mathrm{L}$ of the prepared broth was distributed; subsequently, serial dilution of the extract solution was performed obtaining concentrations ranging from 500 to $0.5 \mu \mathrm{g} / \mathrm{mL}$. Well number 12 was left free from the plant material and was considered a control for microbial growth. A fresh bacterial colony was picked from an overnight agar culture and was prepared to match the turbidity of the $0.5 \mathrm{McFarland}$ standard to provide a bacterial suspension of $1.5 \times 10^{8}$ colony forming units $(\mathrm{CFU}) / \mathrm{mL}$. This suspension was diluted with broth by a ratio of 1:3 to reach $5 \times 10^{7} \mathrm{CFU}$. Then, $1 \mu \mathrm{L}$ of the bacterial suspension was added to all of the wells except well number 11, which was considered as a negative control for microbial growth. The plate was then incubated at $35^{\circ} \mathrm{C}$ for $18 \mathrm{~h}$.

The microdilution method for the yeast C. albicans was performed as described above, except that after matching the yeast suspension with the McFarland standard, which was diluted with $\mathrm{NaCl}(0.9 \%)$ by a ratio of $1: 50$, followed by $1: 20$, and $100 \mu \mathrm{L}$ was placed in the wells. The plate was incubated for $48 \mathrm{~h}$ instead of $18 \mathrm{~h}$.

The agar dilution method was carried out to investigate the antimold activity of FFM against Epidermatophyton floccosum. Sabouraud dextrose agar $(1 \mathrm{~mL})$ was placed in each test tube and kept at $40{ }^{\circ} \mathrm{C}$ in a water bath. Then, FFM $(1 \mathrm{~mL})$ was mixed with Sabouraud dextrose agar $(1 \mathrm{~mL})$ in the first tube and serial dilutions were performed in six tubes. Tube number 6 was kept free of any plant material and was considered as a negative control for microbial growth. 
After the Sabouraud dextrose agar was solidified, the spores of the mold culture were dissolved in distilled water containing $0.05 \%$ Tween 80 and scratched from the plate for comparison with McFarland turbidity. Twenty microliters of the obtained suspension was pipetted into all of the tubes except tube number 5 , which was considered as a negative control. The tubes were incubated at $25{ }^{\circ} \mathrm{C}$ for 14 days [55].

In the current antimicrobial experiments, ampicillin, ciprofloxacin and fluconazole, (powder purity $\geq 98 \%$ ), which all obtained from Sigma-Aldrich (Germany), were utilized as positive controls and prepared via the above-mentioned method. Each experimental work was repeated in triplicates.

\subsection{Statistical Characterizations}

The conducted experiments were determined in triplicates. The results are presented as means \pm standard deviation (SD). GLUT4-myc translocation results are presented as the mean \pm SEM. The data were analyzed using $t$-test statistical calculations conducted with the SPSS version 21.0 software. When comparing samples, differences were considered statistically significant when $p<0.05$.

\section{Conclusions}

The current investigation documented for the first time the chemical components of M. autumnalis ripe fruit flavonoid fraction and evaluated its antidiabetic, DPPH scavenging, antiobesity, cytotoxic and antimicrobial effects. Four flavonoids were isolated and characterized from the flavonoids fraction, namely kaempferol 1, luteolin 2, myricetin 3 and (+)-taxifolin 4. The results indicate that FFM dramatically increased the amount of GLUT4 in the PM in both the presence and the absence of insulin. These findings suggest that FFM has anti-diabetic properties. Furthermore, FFM revealed $\alpha$-amylase and $\alpha$-glucosidase inhibitory characteristics and was shown to have strong DPPH scavenging and porcine pancreatic lipase inhibitory activities. In addition, FFM inhibited the growth of all of the tested bacterial and fungal strains and showed the greatest antibacterial activity against the K. pneumoniae strain. Moreover, the cytotoxicity screening showed that FFM is found to be safe up to $1 \mathrm{mg} / \mathrm{mL}$. Future plans are required to confirm these very important outcomes by in vivo trials and to design suitable formulations to be used in the pharmaceutical and food supplement industries.

Supplementary Materials: The supplementary material shows supplementary figures regarding the ${ }^{1} \mathrm{H}$ and ${ }^{13} \mathrm{C}-\mathrm{NMR}$ spectrums. Figure S1: ${ }^{1} \mathrm{H}$ NMR spectrum $(400 \mathrm{MHz})$ of kaempferol 1 in DMSO- $\mathrm{d}_{6}$; Figure S2: ${ }^{13} \mathrm{C}$ NMR spectrum (DEPT) $(400 \mathrm{MHz})$ of 1 in DMSO-d $\mathrm{d}_{6}$; Figure S3: ${ }^{1} \mathrm{H}-{ }^{1} \mathrm{H}$ COSY spectrum of $\mathbf{1}$ in DMSO- $\mathrm{d}_{6}$; Figure S4: HSQC spectrum of $\mathbf{1}$ in DMSO- $\mathrm{d}_{6}$; Figure S5: ${ }^{1} \mathrm{H}$ NMR spectrum $(400 \mathrm{MHz})$ of luetolin 2 in DMSO- $\mathrm{d}_{6}$; Figure S6: Expansion of the aromatic region of ${ }^{1} \mathrm{H}$ NMR spectrum of 2 in DMSO- $\mathrm{d}_{6}:$; Figure S7: ${ }^{13} \mathrm{C}$ NMR spectrum (DEPT) (400 MHz) of 2 in DMSO- $\mathrm{d}_{6}$; Figure S8: ${ }^{1} \mathrm{H}$ NMR spectrum $(400 \mathrm{MHz})$ of myricetin 3 in DMSO-d $\mathrm{d}_{6}$; Figure S9: ${ }^{13} \mathrm{C}$ NMR spectrum (DEPT) $(400 \mathrm{MHz})$ of 3 in DMSO-d ${ }_{6}$; Figure S10: ${ }^{1} \mathrm{H}$ NMR spectrum (400 MHz) of (+)-taxifolin 4 in DMSO- $\mathrm{d}_{6}$; Figure S11: ${ }^{13} \mathrm{C}$ NMR spectrum $(400 \mathrm{MHz})$ of 4 in DMSO- $\mathrm{d}_{6}$; Figure S12: HSQC spectrum of 4 in DMSO- $\mathrm{d}_{6}$; Figure S13: ${ }^{1} \mathrm{H}_{-}{ }^{1} \mathrm{H}$ COSY spectrum of 4 in DMSO- $\mathrm{d}_{6}$; Figure S14: HMBC spectrum of 4 in DMSO- $\mathrm{d}_{6}$.

Author Contributions: Conceptualization, N.J and N.A.-M.; methodology, N.A.-M. and N.J.; software, N.A.-M., N.J., M.H., N.B. and H.Z.; validation, N.A.-M., N.J., M.H., N.B. and H.Z.; formal analysis, N.A.-M., N.J. and M.H. and N.B.; investigation, N.A-M. and N.J.; resources, N.A.-M., N.J., M.H., N.B. and H.Z.; data curation, M.H., N.B., N.A-M. and N.J.; writing-original draft preparation, N.A.-M. and N.J.; writing-review and editing, N.A.-M. and N.J.; visualization, N.A.-M. and N.J.; supervision, N.A.-M. and N.J. All authors have read and agreed to the published version of the manuscript.

Funding: This research received no external funding.

Institutional Review Board Statement: Not applicable.

Informed Consent Statement: Not applicable. 
Data Availability Statement: All data is contained within the article.

Acknowledgments: The authors would like to thank An-Najah National University and Arab American University Jenin.

Conflicts of Interest: The authors declare that there are no conflict of interest.

\section{References}

1. Preedy, V.R.; Watson, R.R. Nuts and Seeds in Health and Disease Prevention; Academic Press: Cambridge, MI, USA, 2020.

2. Ekor, M. The growing use of herbal medicines: Issues relating to adverse reactions and challenges in monitoring safety. Front. Pharmacol. 2014, 4, 177-187. [CrossRef] [PubMed]

3. Alamgir, A. Therapeutic Use of Medicinal Plants and Their Extract; Springer: New York, NY, USA, 2018.

4. Azab, A. Solanaceae plants of Israel and Palestine-rich source of medicinally active natural products. Eur. Chem. Bull. 2020, 9, 199-261. [CrossRef]

5. Alzweiri, M.; Al Sarhan, A.; Mansi, K.; Hudaib, M.; Aburjai, T. Ethnopharmacological survey of medicinal herbs in Jordan, the Northern Badia region. J. Ethnopharmacol. 2011, 137, 27-35. [CrossRef] [PubMed]

6. Mahmod, A.I.; Talib, W.H. Anticancer activity of Mandragora autumnalis: An in vitro and in vivo study. Pharmacia 2021, 4, 827-836. [CrossRef]

7. Jodallah, N.B.E. Antioxidant and Antimicrobial Activity of Mandragora Autumnalis Bertol Extracts; An-Najah National University: Nablus, Palestine, 2013.

8. Uysal, S.; Zengin, G.; Aktümsek, A. Antioxidant properties and enzyme inhibitory effects of extracts from Mandragora autumnalis and its fatty acid composition. Marmara Pharm. J. 2016, 20, 144-151. [CrossRef]

9. Casini, E. Rethinking the Multifaceted Aspects of Mandrake in Ancient Egypt; Pisa University Press: Pisa, Italy, 2017.

10. Al-Dinawari, B. Botany, Herbals and Healing in Islamic Science and Medicine; FSTC Ltd.: Manchester, UK, 2009.

11. Hanuš, L.O.; Řezanka, T.; Spížek, J.; Dembitsky, V.M. Substances isolated from Mandragora species. Phytochemistry 2005, 66, 2408-2417. [CrossRef]

12. Tuttolomondo, T.; Licata, M.; Leto, C.; Savo, V.; Bonsangue, G.; Gargano, M.L.; Venturella, G.; La Bella, S. Ethnobotanical investigation on wild medicinal plants in the Monti Sicani Regional Park (Sicily, Italy). J. Ethnopharmacol. 2014, 153, 568-586. [CrossRef]

13. Jackson, B.P.; Berry, M.I. Mandragora-Taxonomy and Chemistry of the European Species; Academic Press: London, UK, 1979.

14. Suleiman, R.K.; Zarga, M.A.; Sabri, S.S. New withanolides from Mandragora officinarum: First report of withanolides from the genus Mandragora. Fitoterapia 2010, 81, 864-868. [CrossRef]

15. Suvan, J.E.; Finer, N.; D'Aiuto, F. Periodontal complications with obesity. Periodontol. 2000 2018, 78, 98-128. [CrossRef]

16. Gashaw, M.; Berhane, M.; Bekele, S.; Kibru, G.; Teshager, L.; Yilma, Y.; Ahmed, Y.; Fentahun, N.; Assefa, H.; Wieser, A. Emergence of high drug resistant bacterial isolates from patients with health care associated infections at Jimma University medical center: A cross sectional study. Antimicrob. Resist. Infect. Control 2018, 7, 1-8. [CrossRef]

17. Dadgostar, P. Antimicrobial resistance: Implications and costs. Infect. Drug Resist. 2019, 12, 3903-3910. [CrossRef]

18. Chanda, S.; Tiwari, R.K.; Kumar, A.; Singh, K. Nutraceuticals inspiring the current therapy for lifestyle diseases. Adv. Pharmacol. Sci. 2019, 2019, 6908716. [CrossRef]

19. Lou, H.; Hu, L.; Lu, H.; Wei, T.; Chen, Q. Metabolic Engineering of Microbial Cell Factories for Biosynthesis of Flavonoids: A Review. Molecules 2021, 26, 4522. [CrossRef]

20. Liu, H.; Mou, Y.; Zhao, J.; Wang, J.; Zhou, L.; Wang, M.; Wang, D.; Han, J.; Yu, Z.; Yang, F. Flavonoids from Halostachys caspica and their antimicrobial and antioxidant activities. Molecules 2010, 15, 7933-7945. [CrossRef]

21. Monadi, T.; Azadbakht, M.; Ahmadi, A.; Chabra, A. A Comprehensive Review on the Ethnopharmacology, Phytochemistry, Pharmacology, and Toxicology of the Mandragora Genus; from Folk Medicine to Modern Medicine. Curr. Pharm. Des. 2021, 27, 3609-3637. [CrossRef]

22. Wawer, I.; Zielinska, A. ${ }^{13}$ C CP/MAS NMR studies of flavonoids. Magn. Reson. Chem. 2001, 39, 374-380. [CrossRef]

23. Lin, L.-J.; Huang, X.-B.; Lv, Z.-C. Isolation and identification of flavonoids components from Pteris vittata L. Springerplus 2016, 5, 1-3. [CrossRef]

24. Shen, C.-C.; Chang, Y.-S.; Ho, L.-K. Nuclear-magnetic-resonance studies of 5, 7-dihydroxyflavonoids. Phytochemistry 1993, 34, 843-845. [CrossRef]

25. Wang, L.; Li, X.; Zhang, S.; Lu, W.; Liao, S.; Liu, X.; Shan, L.; Shen, X.; Jiang, H.; Zhang, W. Natural products as a gold mine for selective matrix metalloproteinases inhibitors. Bioorg. Med. Chem. 2012, 20, 4164-4171. [CrossRef]

26. Sheliya, M.A.; Rayhana, B.; Ali, A.; Pillai, K.K.; Aeri, V.; Sharma, M.; Mir, S.R. Inhibition of $\alpha$-glucosidase by new prenylated flavonoids from Euphorbia hirta L. herb. J. Ethnopharmacol. 2015, 176, 1-8. [CrossRef]

27. Röder, P.V.; Wu, B.; Liu, Y.; Han, W. Pancreatic regulation of glucose homeostasis. Exp. Mol. Med. 2016, 48, e219. [CrossRef]

28. Echeverría, C.; Nualart, F.; Ferrada, L.; Smith, G.J.; Godoy, A.S. Hexose transporters in cancer: From multifunctionality to diagnosis and therapy. Trends Endocrinol. Metab. 2021, 32, 198-211. [CrossRef]

29. AL-Ishaq, R.K.; Abotaleb, M.; Kubatka, P.; Kajo, K.; Büsselberg, D. Flavonoids and their anti-diabetic effects: Cellular mechanisms and effects to improve blood sugar levels. Biomolecules 2019, 9, 430. [CrossRef] 
30. Choi, H.-N.; Kang, M.-J.; Lee, S.-J.; Kim, J.-I. Ameliorative effect of myricetin on insulin resistance in mice fed a high-fat, high-sucrose diet. Nutr. Res. Pract. 2014, 8, 544-549. [CrossRef]

31. Alkhalidy, H.; Moore, W.; Zhang, Y.; McMillan, R.; Wang, A.; Ali, M.; Suh, K.-S.; Zhen, W.; Cheng, Z.; Jia, Z. Small molecule kaempferol promotes insulin sensitivity and preserved pancreatic $\beta$-cell mass in middle-aged obese diabetic mice. J. Diabetes. Res. 2015, 2015, 532984. [CrossRef]

32. Proença, C.; Freitas, M.; Ribeiro, D.; Tomé, S.M.; Oliveira, E.F.; Viegas, M.F.; Araújo, A.N.; Ramos, M.J.; Silva, A.M.; Fernandes, P.A. Evaluation of a flavonoids library for inhibition of pancreatic $\alpha$-amylase towards a structure-activity relationship. J. Enzyme Inhib. Med. Chem. 2019, 34, 577-588. [CrossRef]

33. Barber, E.; Houghton, M.J.; Williamson, G. Flavonoids as human intestinal $\alpha$-glucosidase inhibitors. Foods 2021, $10,1939$. [CrossRef]

34. Tadera, K.; Minami, Y.; Takamatsu, K.; Matsuoka, T. Inhibition of $\alpha$-glucosidase and $\alpha$-amylase by flavonoids. J. Nutr. Sci. Vitaminol. 2006, 52, 149-153. [CrossRef]

35. Zhu, J.; Chen, C.; Zhang, B.; Huang, Q. The inhibitory effects of flavonoids on $\alpha$-amylase and $\alpha$-glucosidase. Crit. Rev. Food Sci. Nutr. 2020, 60, 695-708. [CrossRef]

36. Rahman, M.M.; Islam, M.B.; Biswas, M.; Alam, A.K. In vitro antioxidant and free radical scavenging activity of different parts of Tabebuia pallida growing in Bangladesh. BMC Res. Notes 2015, 8, 621. [CrossRef]

37. Khan, M.A.; Rahman, A.A.; Islam, S.; Khandokhar, P.; Parvin, S.; Islam, M.B.; Hossain, M.; Rashid, M.; Sadik, G.; Nasrin, S. A comparative study on the antioxidant activity of methanolic extracts from different parts of Morus alba L. (Moraceae). BMC Res. Notes 2013, 6, 24. [CrossRef] [PubMed]

38. Huang, D.; Ou, B.; Prior, R.L. The chemistry behind antioxidant capacity assays. J. Agric. Food Chem. 2005, 53, 1841-1856. [CrossRef] [PubMed]

39. Sim, G.-S.; Lee, B.-C.; Cho, H.S.; Lee, J.W.; Kim, J.-H.; Lee, D.-H.; Kim, J.-H.; Pyo, H.-B.; Moon, D.C.; Oh, K.-W. Structure activity relationship of antioxidative property of flavonoids and inhibitory effect on matrix metalloproteinase activity in UVA-irradiated human dermal fibroblast. Arch. Pharm. Res. 2007, 30, 290-298. [CrossRef] [PubMed]

40. Oussaada, S.M.; van Galen, K.A.; Cooiman, M.I.; Kleinendorst, L.; Hazebroek, E.J.; van Haelst, M.M.; ter Horst, K.W.; Serlie, M.J. The pathogenesis of obesity. Metabolism 2019, 92, 26-36. [CrossRef]

41. Jaradat, N.; Zaid, A.N.; Hussein, F.; Zaqzouq, M.; Aljammal, H.; Ayesh, O. Anti-lipase potential of the organic and aqueous extracts of ten traditional edible and medicinal plants in palestine; a comparison study with orlistat. Medicines 2017, 4, 89. [CrossRef]

42. Shimura, S.; Itoh, Y.; Yamashita, A.; Kitano, A.; Hatano, T.; Yoshida, T.; Okuda, T. Inhibitory effects of flavonoidson lipase. Nippon Shokuhin Kogyo Gakkaishi 1994, 41, 847-850. [CrossRef]

43. Abou-El-Naga, I.; Said, D.; Gaafar, M.; Ahmed, S.; El-Deeb, S. A new scope for orlistat: Effect of approved anti-obesity drug against experimental microsporidiosis. Med. Mycol. 2019, 57, 181-195. [CrossRef]

44. Obeidat, M. Antimicrobial activity of some medicinal plants against multidrug resistant skin pathogens. J. Med. Plant Res. 2011, 5, 3856-3860.

45. Ayaz, F.A.; Hayırlıglu-Ayaz, S.; Alpay-Karaoglu, S.; Grúz, J.; Valentová, K.; Ulrichová, J.; Strnad, M. Phenolic acid contents of kale (Brassica oleraceae L. var. acephala DC.) extracts and their antioxidant and antibacterial activities. Food Chem. 2008, 107, 19-25. [CrossRef]

46. Rahman, M.A.A.; Moon, S.-S. Antimicrobial phenolic derivatives from Dendranthema zawadskii var. latilobum kitamura (Asteraceae). Arch. Pharm. Res. 2007, 30, 1374-1379. [CrossRef]

47. Sarian, M.N.; Ahmed, Q.U.; Mat So'ad, S.Z.; Alhassan, A.M.; Murugesu, S.; Perumal, V.; Syed Mohamad, S.N.A.; Khatib, A.; Latip, J. Antioxidant and antidiabetic effects of flavonoids: A structure-activity relationship based study. Biomed. Res. Int. 2017, 2017, 8386065. [CrossRef]

48. Xie, Y.; Yang, W.; Tang, F.; Chen, X.; Ren, L. Antibacterial activities of flavonoids: Structure-activity relationship and mechanism. Curr. Med. Chem. 2015, 22, 132-149. [CrossRef]

49. Mosmann, T. Rapid colorimetric assay for cellular growth and survival: Application to proliferation and cytotoxicity assays. $J$. Immunol. Methods 1983, 65, 55-63. [CrossRef]

50. Kadan, S.; Sasson, Y.; Zaid, H. Portulaca oleracea L. extracts enhance GLUT4 translocation to the surface of muscle cells in insulin dependent and independent fashion. Adv. Med. Plant Res. 2019, 7, 85-90. [CrossRef]

51. Zaid, H.; Talior-Volodarsky, I.; Antonescu, C.; Liu, Z.; Klip, A. GAPDH binds GLUT4 reciprocally to hexokinase-II and regulates glucose transport activity. Bioch. J. 2009, 419, 475-484. [CrossRef]

52. Ali, H.; Houghton, P.; Soumyanath, A. $\alpha$-Amylase inhibitory activity of some Malaysian plants used to treat diabetes; with particular reference to Phyllanthus amarus. J. Ethnopharmacol. 2006, 107, 449-455. [CrossRef]

53. Kim, J.-S.; Kwon, C.-S.; Son, K.H. Inhibition of alpha-glucosidase and amylase by luteolin, a flavonoid. Biosci. Biotechnol. Biochem. 2000, 64, 2458-2461. [CrossRef]

54. Jaradat, N.A.; Abualhasan, M. Comparison of phytoconstituents, total phenol contents and free radical scavenging capacities between four Arum species from Jerusalem and Bethlehem. Pharm. Sci. 2016, 22, 120-125. [CrossRef]

55. Falahati, M.; Omidi Tabrizib, N.; Jahaniani, F. Anti dermatophyte activities of Eucalyptus camaldulensis in comparison with Griseofulvin. Iran. J. Pharmacol. Ther. 2005, 4, 80-100. 